\title{
NARRATIVE REPRESENTATIONS OF MASCULINITY. THE HARD WEREWOLF AND THE ANDROGYNOUS VAMPIRE IN ANITA BLAKE: VAMPIRE HUNTER SERIES
}

\author{
VIRGINIA FusCo \\ Carlos III University of Madrid \\ vfusco@hum.uc3m.es
}

\begin{abstract}
Laurell Hamilton in her Anita Blake: Vampire Hunter Series portrays a large community of monstrous creatures that populate a violent near-future American landscape. A number of critics have already explored the forms in which Anita, the leading heroine, emerges in the 1990s literary scene as a strong figure who challenges traditional narratives of female subordination and alters predictable romantic entanglements with the male protagonists (Crawford 2014; Veldman-Genz 2011; Siegel 2007; Holland-Toll 2004). Moving beyond this approach that centres on Anita, this paper explores the forms in which the author designs her male companions and lovers. Her choice of lovers suggests that there are multiple desires at play in Hamilton's popular fiction in relation to masculinity in the context of a heterosexual erotica. Following a methodological approach of cultural studies (Saukko 2003), this study seeks to illustrate how conflicting desires, emblemized by her plurality of lovers, represent a literary effect of paradoxical yearnings at play in contemporary white, middle-class American women's lives.
\end{abstract}

Keywords: Hard masculinity, androgyny, werewolf, vampire, Anita Blake: Vampire Hunter Series. 
VIRGINIA FUSCO

\title{
REPRESENTACIONES LITERARIAS DE LA MASCULINIDAD. EL DURO HOMBRE-LOBO Y EL VAMPIRO ANDRÓGINO EN LA SERIE ANITA BLAKE: CAZAVAMPIROS
}

\begin{abstract}
RESUMEN. Laurell Hamilton en su saga Anita Blake: Vampire Hunter presenta una nutrida comunidad de criaturas monstruosas que pueblan un paisaje norteamericano violento en un futuro cercano. Numerosos críticos han explorado ya las formas en que Anita, la heroina principal, emerge en la escena literaria en los 1990 s como una figura fuerte que cuestiona las narrativas tradicionales de subordinación femenina y altera los predecibles enredos románticos con los protagonistas masculinos (Crawford 2014; Veldman-Genz 2011; Siegel 2007; Holland-Toll 2004). Más allá de esta aproximación que se centra en Anita, este artículo explora los modos en que la autora construye los personajes de sus compañeros y amantes masculinos. Su elección de amantes sugiere que hay múltiples deseos en juego en la ficción popular de Hamilton en lo que se refiere a la masculinidad en el contexto de una erótica heterosexual. Siguiendo un enfoque metodológico de los estudios culturales (Saukko 2003), este estudio busca ilustrar cómo los deseos en conflicto, simbolizados en una pluralidad de amantes, representan un efecto literario de los anbelos paradójicos en juego en las vidas de las mujeres americanas contemporáneas de clase media.
\end{abstract}

Palabras clave: Masculinidad dura, androginia, hombre-lobo, vampiro, saga Anita Blake: Vampire Hunter.

Received 12 May 2016

Revised version accepted 14 July 2017

\section{INTRODUCTION}

\begin{abstract}
Masculinity and femininity are inherently relational concepts, which have meaning in relation to each other, as a social demarcation and a cultural opposition. This holds regardless of the changing content of the demarcation in different societies and periods of history. (Connell 1995: 44)
\end{abstract}

In other words, according to Raewyn Connell, gender roles and ideals -in fiction as well as in reality - are mutually constructed and they continue to dialogue and metamorphose over time. I define this 'dialogue' between masculinity and femininity as a game of alterities that largely determines the way in which social, economic, and political transformations in the condition of women are mirrored by changes in the way men are perceived or in the ways in which particular 'modes' of being a woman or man are privileged in a given cultural context. For 
the purpose of my argument, I will focus primarily on the ways in which desirable and undesirable men are presented and represented in cultural artefacts; in fact, un/desirable types of masculinity could function simultaneously as reminders of what is (currently) socially acceptable or promote anti-hegemonic discourse on masculinity, picturing alternative forms of being a male (Horlacher 2011). According to this dialogical understanding of gender roles and expectations, an exploration of the ways in which Hamilton depicts her male characters will reveal how the character of Anita Blake came to life while at the same time disclosing how the series - through this heroine engaged with a variety of supernatural creaturesemblemizes different forms of masculinity that appear desirable to a large female audience.

To situate the symbolic discursive constructions of desirable types of masculinity in the Hamilton's novels, I have referred to Elisabeth Badinter's depictions of the Hard Man/Soft Man/Androgyne (1993) and to Reawyn Connell's (1995) and Michael Kimmel's (2013) writings on masculinity. The authors provide the theoretical framework to closely address complex issues such as identity, performativity, and gender violence in this North American literary production. In particular, these authors have sought to account for the challenges posed by feminism and socioeconomic mutations to a traditional 'ideal man' that had historically colonized the middle-class white imaginary in the Anglo-Saxon world and has dominated both women and men in real life.

\section{THE HARD AND THE SOFT: A CARTOGRAPHY}

In spite of the presence of a vast number of lover-boys in Hamilton's books, I will focus my attention on Richard Zeeman (the 'macho' werewolf) and Jean Claude (the androgynous vampire) because these two remain constantly present in her promiscuous love life. Indeed Richard and Jean Claude constitute two very different forms of being male. Richard, the ideal boyfriend, turns out to be a domineering macho that shows no respect for her independence or freedom and is caught in a spiral of violence that he exercises against himself and other wereanimals. In his relationship with Anita, he tends to maintain excessive vigilance and to hate those that are close to her, one way or another. On the other hand, Jean Claude, despite all his flaws as a lover - the romantic ideal of the perfect match is not present in Anita's world - is portrayed as a better choice because he is sensitive and understanding without being 'soft' and maintains a high degree of power associated with a traditional form of masculinity. This ability to show strategic gender role playing and emotional adaptability indeed makes him a most desirable 'androgyne', a reconciled man. 
The term 'androgyny', as is widely known, comes from the fusion of two Greek words: anér-andros $=$ man and gyné-gynaicos = woman. The etymology of the word has allowed the emergence, in the modern era, of a multiplicity of interpretations that have been adopted in many feminist literary creations from Orlando onwards (Heilbrun 1964). On the one hand, the reference to duality encapsulated in the word has led critics and writers to embrace the blending of differences into a unity that transcends the specificity of the two, a 'neutral being' not controlled by gender. On the other hand, it has generated a reading of the figure that would allow the co-existence of the two, either as the 'feminisation of the male' or 'masculinisation of the female' (Goodlad 2007). Beyond these traditional interpretations, the French philosopher Elisabeth Badinter in her XY de L'Identité masculine (1992) suggests that the acquisition of androgyny represents a process of integration, somehow a form of styling the self versus a form of conceiving of it as a given expression of a double nature (1993: 224). The self-styled 'androgynous' individual could consciously use a number of strategies that have been historically identified as feminine or masculine to cope with the challenges at hand, positioning his/her feminist project alongside queer readings of gender as performance even though Badinter's model rests on a notion of embedded psychological dualism absent in more recent feminist works (Butler 1990). Far from being an ideal type, the contemporary 'androgyne' constitutes a competent human that shows an agile adaptability, constantly zigzagging between compassion, soft-heartedness, affection, sensitivity, tolerance and ambition, toughness, practicality, and courage (Woodhill and Samuels 2004). The androgyn has the potential of becoming a fully integrated man and/or woman and does not himself/herself constitute a separate/ third gender/sex. Removing the utopian element of a genderless society so dear to science-fiction and Gothic authors (Morgan 1987) and to some critics (Rubin 1975), Badinter offers an alterative way of interpreting contemporary gendered subjectivities in cultural texts.

Badinter reconsiders and summarizes some of the debates that emerged in the 1980s on the condition of men in a world where feminism has exerted — together with socioeconomic transformations - a huge impact in people's perceptions of how relationships should be established, which attitudes and attributes are desirable in a man and what roles and obligations are to be claimed in intimate contexts (the family and the 'private'). Women joining the labour market and the feminist movement in its intent to conquer terrain inside and outside the claustrophobic house of the Patriarch, forever changed gender relations, altering women's expectations of men and questioning the forms in which traditional gender roles were being enacted in the secluded family environment. In fact, 
with the emergence of feminist consciousness and sensitivity, some of the traditional behaviour and practices attributed to men are heavily criticized and new forms of 'being a man in the world' become recognized as desirable. Ideals and practices that have historically defined masculinity were effectively proven not to be trans-historical or universal natural constituents of manhood, but instead found to be generated in political and economic contexts that frame the 'social conditions of possibility' of gendered subjectivity (Whitehead 2002; Adams and Savran 2002).

Masculinity is not a fixed entity embedded in the body or personality traits of individuals. Masculinities are configurations of practice that are accomplished in social action and, therefore, can differ according to the gender relations in a particular social setting. (Connell and Messerschmidt 2005: 836)

The struggle to acquire traditional American masculinity and the imperative of its never-ending performance has been harmful for men, both for those who were depicted as real men as much as for those who, by contrast, were suspected of being homosexual or effeminate and, therefore, not quite so 'real'. Due to the emergence of feminism, the traditional Hard Man American felt at risk of being replaced by men embracing other forms of manliness much more humane and desirable for the New Woman, who was increasingly concerned with the amount of violence that traditional men expressed against women in their attempt to maintain their sense of manhood and their feeling of being in control (Faludi 1999). Thus, following the imperative 'Give'em Hell' (Badinter 1993: 179) that insists on compulsory strength as a marker of manliness and the (potential) use of violence, the Hard Man struggled to establish a self-assuring sense of superiority and of being in command.

If one looks at the specificity of hard manliness in the context of contemporary America, Michael Kimmel's most recent socio-analysis of white masculinity(s) helps to explore the specific forms in which such changes - magnified by globalization, economic/financial crisis, and natural disasters - are threatening the white American imagination. In this text, he claims:

If masculinity is based on impermeable defences and the feeling of being in control, then violence may be restorative, returning the situation to the moment before that sense of vulnerability and dependency was felt and one's sense of masculinity was so compromised. [...] use violence as a means of restoring what was experienced as threatened, that part of the self that is suddenly made vulnerable. (Kimmel 2013: 177)

Thus, far from being a natural mode of being a man, the Hard is currently the expression of a desire to be in control that has been progressively eroded by feminism and, simultaneously, by contemporary socio-economic mutations that 
have dramatically altered the possibilities of well-being in contemporary America. All these elements pose a serious challenge to the idea that white men were enjoying a superior power position in relation to a variety of others because they were naturally entitled to it:

The surge in aggression from America's angry white men comes not only from the gradual dispossession of white men from virtually every single position of power and authority in the land, but also from the challenge to their sense that such positions are their birthright (Kimmel 2013: 177).

Furthermore:

The new American anger [...] seeks to restore, to retrieve, to reclaim something that is perceived to have been lost. Angry White Men look to the past for their imagined and desired future. They believe that the system is stacked against them. Theirs is the anger of the entitled: we are entitled to those jobs, those positions of unchallenged dominance. (Kimmel 2013: 21)

Considering the impact of these presuppositions on the psychic makeup of the Hard Man, Badinter coins another name for him: the Knot Man, in reference to both his traditional look and his emotional 'knots'. The Knot Man wears a suit and a tie like any other successful businessman of his generation and his emotions are in turn knotted up to guarantee that he is always tense and implicitly ready for a fight. In other words, the Hard represents a combination of the worst masculine stereotypes: he is very competitive, self-involved to the extreme and emotionally impaired (Badinter 1993: 176). Indeed, he is no sissy, a big wheel, a sturdy oak and he shouts: Give them Hell! (Badinter 1993: 179).

Despite the amount of privileges that he enjoys in patriarchy, the Hard type stands for a man that has been emotionally amputated and has to resign himself to a life deprived of emotions and caring, both in the form of being cared about and caring for someone else. Furthermore, the obsession with homosexuality and effeminacy that have characterized the emergence of nineteenth middle-class discourses on manliness is paired with the psychic imperative of not showing any sign of femininity, if a man wishes to enjoy a higher degree of power in real life. Badinter seems to suggest that, for these very reasons, men are socially encouraged to cut off the ability to feel and are destined either to live a sterile life or to become self-destructive neurotics. The Hard type, in short, represents the prototype of a man with a high connection to violence. He is a vital threat in his mad, desperate effort to maintain dominance both over other men and over women.

This exclusion of femininity that underlies the configuration of the Hard seems to work on two different interdependent levels: the social and the psychological. 
In Connell's theorizing, Hard options operate through the policing of men and the exclusion of women, giving his work primarily a sociological focus:

To sustain a given pattern of hegemony requires the policing of men as well as the exclusion or discrediting of women. Evidence of such mechanisms ranges from the discrediting of 'soft' options in the hard world [...], to homophobic assaults and murders $[\ldots .$.$] , all the way to the teasing of boys in school for 'sissiness'. (Connell$ and Messerschmidt 2005: 840)

On the other hand, when considering the psychological impact of hard options, Connell emphases how they require to be thought of as damaging factors for men in their gendered performances, in spite of the positive social and political recognition such performances might entail (Connell and Wood 2005).

At the opposite end of the symbolic spectrum, we would encounter the Soft Man, i.e. the perfect match for a strong-willed woman. This is a man who would renounce his masculinity in order to embrace his psychic feminine side. The Soft type represents an adaptive response to the challenges posed by feminism and by mutated socio-economic conditions of reproduction; he is the converse of the Hard Man, his alter ego. While the Hard inhibits his femininity to the extreme, the Soft ignores his masculinity, turning into a female actor with male anatomy (Badinter 1993: 175). He is the good partner, being the one who does the dishes and who would surrender to provide love and care. He places himself at the total disposal of others, 24 hours a day. His form of being a man implies the mutilation of the masculine or, stated differently, his manhood is characterised by his unwillingness to perform socially according to traditional gendered normative roles (Rodgers 1995).

This dichotomy, which enforces social practices, leaves men with no way out. In both scenarios men find themselves psychically impaired, being either victims of hate against all 'others' or unable to cope with the problematic discursive construction of a dualistic notion of gendered subjectivities in conflict.

All this considered, lets now look at Richard - the werewolf - as an example of a literary man dangerously shifting towards a violent traditional form of white masculinity.

\section{RICHARD ZEEMAN: MOVING TOWARDS HARDNESS}

Richard Zeeman is one of Anita's primary love interests. Hamilton introduces him quite early in the series, i.e. in The Circus of the Damned, the third novel published in 1995. He is given much attention at the beginning because he is coded as the natural choice as a partner for a Christian, law-abiding young 
woman. He is in fact described as a reassuring human, an appealing alternative to the insinuating vampire that we have known since Guilty Pleasures. He is a junior high school science were-teacher driven by his job that has decided to hide his lycanthropy from everyone to avoid putting his professional life at risk.

"How do you know so much about lycanthropes?" "It's my job," he said, "I teach science at a local junior high." I just stared at him. "You're a junior high science teacher?" "Yes." He was smiling. "You looked shocked." I shook my head. "What's a school teacher doing messed up with vampires and werewolves?" (Hamilton 1995: 48)

In Hamilton's fantasy world, the violent nature of werewolves is considered a threat to humans, making it impossible to maintain a job for those that have been infected, especially when they are dealing with the youth or working in the health sector in which the exposure to blood can lead to further contagion.

Richard's appearance is deceiving: he looks like any other ordinary human, an innocent bystander in the never-ending fight between mortals and supernatural creatures. In other words, Anita starts a relationship with him in the hope of not getting too involved with the preternatural community and wishing to resist vampire seduction. He seems like a nice fellow: healthy, attractive.

Richard's hands were clasped loosely around one knee. He was wearing white Nikes with a blue swoosh, and no socks. Even his ankles were tan. His thick hair brushed the tops of his naked shoulders. His eyes were closed. I could gaze at his muscular upper body as long as I wanted to [...]. I approved. (Hamilton 1995: 46)

Richard is also fond of outdoor activities; as a first date he suggests going caving as 'something unique' they can both enjoy (Hamilton 1995: 63). He is a very refreshing choice, beautiful in his imperfection and extremely different from the ambiguous and plotting vampire that she calls 'monster': "He's a monster, Richard. You've seen him. I can’t love a monster" (Hamilton 1995: 212).

At this point in the saga, she would never go out with monsters so it comes as a shock that the man she ends up dating from the third book on is not a regular human but indeed a werewolf; an alpha in fact that will, by The Killing Dance (Hamilton 1997), turn into an Ulfric, the leader of a wolf clan. Being an alpha means that he has extraordinary physical power, that he might tend to enter struggles for dominance easily and that, as a result, will almost certainly die young. This notion of a premature death, which is a constant source of anxiety for the female lead, matches most statistics on white male youth dying for violence-related injuries (Kimmel 2013; Courtenay 2000). 
Almost from the beginning of their relationship, his were-animal nature — predatory and territorial - manifests itself as a lack of respect for her autonomy that she cannot tolerate, especially when it interferes with her work: "Anita, you've almost died twice today. How can you ..." "Can it, Richard. I need to go to work tonight." [...] "You're right, you're right." His voice was soft. "It just caught me off guard. You nearly died today and you're sitting there drinking coffee like it's ordinary." (Hamilton 1995: 209). Nevertheless, he remains a desirable lover till the climactic explosions of violence in book six. In fact, apart from having a dominant nature he is unable to control, he performs a certain number of activities that make him charming to the eye of the heroine. He is responsible in his job, sustains a satisfactory sexual relationship and desires to be a father, all 'qualities' that have been defined as essential in Connell's definition of hegemonic masculinity as a consensual form of 'being a man':

\begin{abstract}
Most accounts of hegemonic masculinity do include such "positive" actions as bringing home a wage, sustaining a sexual relationship, and being a father. Indeed it is difficult to see how the concept of hegemony would be relevant if the only characteristics of the dominant group were violence, aggression, and selfcenteredness. Such characteristics may mean domination but hardly would constitute hegemony - an idea that embeds certain notions of consent and participation by the subaltern groups. (Connell and Messerschmidt 2005: 840)
\end{abstract}

Indeed, Anita manifests a high degree of compliance/consent towards these practices/attitudes for two reasons that are easily identifiable in the narrative: on the one hand, she codes them as side-effects of his affection and, even more relevant here, she is strongly persuaded that she will be able to turn him into a less violent man. She is depicted, like many women in real life, as a strong believer in the reparatory nature of true love (Gibbons 1992: 154; Norwood 1986). Moreover, and to a certain extent contradictorily, she tolerates his sudden rages and violent outbreaks because they are interpreted as signs of his immutable nature, revealing the implicit danger that traditional conceptions of a supposedly inborn violent essence of men bear for heterosexual women involved with abusive partners.

However, the discovery of his lycanthropy represents a turning point in their relationship. The notion that Anita is engaged with someone that turns hairy once a month is troubling because the 'animal part' we all share becomes dominant and, as a consequence, all the inhibitions and norms are eliminated, turning people into dangerous predators. From this perspective, it may be argued that werewolves are monsters because they evoke both fascination and horrors, being humans that have fully embrace their animality affectively breaking down the ontological barriers between the human and the animal world (Agamben 2002). In other words, the werewolf figuration would work as a reminder of the forever-present animal as an integral part of our human condition. 
The female lead is so upset that she becomes cautious, wondering at times whether he will attack people:

He didn't seem bored or impatient. He seemed to be having a good time watching the people. His eyes followed an elderly couple as they walked through the glass doors. The woman used a cane. Their progress was painfully slow. His head turned slowly with them. I scanned the crowd. Everyone else was younger, moving with confident or hurried stride. Was Richard looking for victims? Prey? He was, after all, a werewolf. (Hamilton 1996: 7)

In The Werewolf Complex, Denis Duclos (1998) provides a key contribution to support my reading of the ways in which hard masculinity is coded in Richard, the dominant were-being. According to the author, representations of the werewolf as a dangerous animal and a potential serial killer are central in the understanding of an American culture that expresses an irrational attraction towards violence as the emblem of a repressive psychosocial order that individual men are caught up in. This repression, together with a variety of other factors, has led to the emergence of the serial killer as a dangerous deviant that has then metamorphosed into a bloodthirsty werewolf. Therefore, Hamilton's decision to attribute traits of this domineering masculinity to a werewolf does not appear the result of a random choice, but corresponds to a general trend in mainstream American cultural production revolving around supernatural creatures.

Moreover, the ways in which those violent practices and attitudes eventually explode into the novels are not coincidental either: the first time she discovers the full extent of Richard rage and uncontrollable nature is when she witnesses him eating a man after a fight for domination, breaking the cultural taboo of cannibalism and, therefore, yielding to his monstrous nature once and for all: "Two alphas fight here tonight. One of us will leave this circle alive. One of us will feed you tonight. Drink of our blood, eat of our flesh. We are pack. We are lukoi. We are one" (Hamilton 1997: 295).

Few pages later, the reader turns into a spectator of Richard's final transformation into a monster when all pretences of humanity slip away:

Marcus drove his claws into Richard's back. Richard tucked his face and neck against the other man's body, protecting himself from the claws. Marcus shuddered. Richard broke away from him, bringing his bloody hand out of Marcus's chest. He tore the still-beating heart out of his chest and flung it to the wolves. They fell on the morsel with small yips and growling [...] When I passed the last furred body, the sound of tearing flesh brought my head around. I couldn't stop myself in time. Richard's muzzle was raised skyward, slick with blood, throwing down a piece of meat that I tried not to recognize. (Hamilton 1997: 299) 
From this moment on, the relationship between the two becomes far more unsettling: they go through stints of open hostility, reconciliation, and friendship. Richard's inability to deal productively with his hardness, his desire to be in control, and his will to dominate sexual partners does not leave much room for trust, a key element of any desirable love bond in fiction as much as in real life.

\section{JEAN-CLAUDE: THE ANDROGYNOUS VAMPIRE}

"This is a place of pleasure, Anita, not violence."

Jean-Claude

Connell points out how maleness has been historically conceived as a quality inherent to the body of a man (Connell 1995: 45); in other words the 'essence of man' makes itself visible through a certain feel of the skin, particular muscular shapes and tensions and a quality of posture and movement that hint at the possibility of (homo)sexual encounters (Connell 1995: 53).

From the very beginning, Jean-Claude's manhood is put into question:

The voice belonged to Jean-Claude, club owner and master vampire. He looked like a vampire was supposed to look. Softly curling hair tangled with the high white lace of an antique shirt. Lace spilled over pale, long-fingered hands. The shirt hung open, giving a glimpse of lean bare chest framed by more frothy lace. Most men couldn't have worn a shirt like that. (Hamilton 1993: 10)

The Master vampire is represented as a combination of masculine physical traits and fragile beauty, a threat to traditional notions of (heterosexual) male good looks. His androgynous appearance is immediately elicited as a form that deconstructs in the flesh traditional attributes of men and women (Mirizio 2000: 133-134). This visual element does not per se clash with the progressive shift in appearance of many heterosexual white men that, since the 1980s, adopted an androgynous style with long hair and a certain display of effeminacy in their choice of clothes (Badinter 1993: 216). Nevertheless, the multiple references to his male lovers and his long-lasting affection for another vampire, Asher, turn JeanClaude into a polyamorous creature not so easily classified.

Indeed, Hamilton's vampirism, exemplified by the vampire Master Jean-Claude, hampers any straightforward gender classification. This symbolic rupture manifests itself at the skin level (looks and texture) as much as in a subtle performance of cross dressing/transvestism that reveals the performative and fluid nature of gender/ sex identifications. His odd taste in clothes, constantly remarked upon, serves to 
accentuate this feeling of estrangement that the novelist exploits to pinpoint JeanClaude's abnormal, threatening, and monstrous androgynous presence. In fact, transgressing against one set of boundaries is 'to call into question the inviolability of both, and of the social codes of sex — already demonstrably under attack- by which such boundaries were policed and maintained' (Garber 1992: 32).

Following up the notion of dialogue between the characters, I wish to remark here that in the narrative, the monstrous body of the vampire - defined by its fragile frame, but equipped with overwhelming force- mirrors the unwomanly qualities of Anita, herself an expression of androgynous 'female masculinity' (Harberstam 1998). As much as Jean-Claude appears simultaneously strong and fragile, the heroine is muscular but extremely delicate like a China doll.

If the looks of this creature, far removed from traditional male beauty and (therefore) essence, make him a potential object of desire for the heroine, even more so does his whole psychology. Jean-Claude is, in fact, coded as an oldfashioned gentleman and, throughout the novels, he is defined repeatedly as sensitive and understanding:

"It is alright, ma petite. We are both safe now." I shook my head against the stained front of his shirt. "It's not that." He touched my face, raised it to look at him in the soft-lighted darkness of the car. "Then what is it?" "I had sex with Micah." I watched his face, waited for the anger, jealousy, something to flash through his eyes. What I saw was sympathy, and I didn't understand it. [...] "You're not angry?" I asked. (Hamilton 2001: 101)

The odd combination of these qualities allows Anita, this vampire hunter deeply submerged in a world of extreme violence and constant threat, to feel safe and cherished:

"I've never seen you be that ... soft with anyone before." It startled me. "You've seen me kiss Richard before." He nodded. "That was lust. This is ..." He shook his head, glancing up at Jean-Claude, then back to me. "He makes you feel safe." I realized with a jolt that he was right. "You're smarter than you look, Zerbrowski." (Hamilton 2001: 100)

Jean-Claude is imagined as a creature through which a set of contradictory time dimensions collapse into a corpse. In fact, his desirability is guaranteed by an immortality that gives him plenty of time to develop and adapt, old age that grants him a pleasant touch of gentlemanliness and his forever-young handsome looks that turn him into a prize. As Mukherjea has stated, supernatural intimacy with the vampire creates a symbolic discursive site in which these time dimensions are simultaneously displayed, allowing for combined traits of desirable masculinity to be performed (Mukherjea 2011). 
If gentlemanliness appears desirable in an androgynous man, it is nonetheless frowned upon when associated with a controlling attitude or a wish to limit the heroine's ability to choose for herself, as it is with Richard. The underlying message is that traditional hard men would use gentlemanliness to derive a certain degree of subordination from their partners. Richard's desire to be the man in the relationship would lead him to fury, to fight with other men for her attention and to actively sabotage her attempts to create a community of men with whom she could emotionally and romantically bond. On the other hand, the androgynous vampire discloses an irresistible combination of gentlemanliness, understanding, and respect for her autonomy. Furthermore, Jean-Claude's strategic adaptability allows him to perform different roles in the novels and make the androgynous man difficult to pigeonhole. The vampire is represented simultaneously as the terrifying body guard, the affectionate and patient lover that will not feel threatened by her multiple lovers, and ultimately, as a mature man that will use his superhuman passion to satisfy her sexually while exercising control over his own devouring nature (he refrains from bloodsucking). In other words, Hamilton's Jean-Claude represents the perfect combination: a mixture between pleasure and danger, incarnated in an undead body, and an almost ideal partner for a contemporary young woman that needs to be supported and understood but cannot do without a high degree of independence.

"I cannot bewitch you with my eyes, and it is harder to cloud your mind, but it can be done." His fingers encircled my arm. Not hurting. I didn't try to pull away. I knew better. He could crush my arm without breaking a sweat, or tear it from its socket, or bench press a Toyota. (Hamilton 1994: 89)

The fiction of immortality and old age appears to be related to desirable masculinity in the form of wealth: Jean-Claude is in fact obscenely rich. He has built up an erotic empire (strip clubs and exotic-dancing theatres) that reinforce his powerbase and guarantee economic prosperity for all those who ally with him. His riches are exemplified by the choice of lush decoration for his residence, expensive clothing, and the possibility of satisfying any lover's desires. Wealth in the form of houses, clubs, bars, and all kinds of property that he owns stand for power and authority. Nevertheless, instead of reproducing the economic dependence of a young female character from a patron in the context of gender/class inequality, Hamilton provides an imagined relationship in which the two are presented as successful professionals, effectively eliminating the possible identification of Jean Claude's sensitivity with Soft Manliness.

Jean-Claude's wealth appears as a sign of desirable entrepreneurship in a man and creates the 'illusion' of a future in which women will have overcome inequality and will have won the struggle for professional recognition and equal 
pay. In other terms, his fortune in contemporary-future America works both as a reminder of how advantageous it is for women to be economically independent in establishing love relations (Radway 1991) and, at the same time, remarks on how wealth is still a very much desired asset in a man.

This particular aspect locates the use of time in Hamilton's series in a very different scenario in relation to vampire canon (Auerbach 1995) and to a great extent marks Hamilton's originality. In Stoker's Dracula, the past was rendered though the depiction of a native land, frozen in time, in which ancient forms of aristocratic domination (Dracula being a Count), resisted the advent of modern times. The lack of capital circulation, exemplified by his habit of accumulating coins, as much as the presence of a variety of ethnic groups prone to superstition, suggested a country deeply unfit for change (Moretti 1982). Dracula himself was described as a being unable to change: through the printed press, phonographs, typewriting, and hypnoses — all part of modern technology - he is ultimately destroyed (Halberstam 1993; Wicke 1992). Contrarily, in Hamilton's fiction for (heterosexual) women, the past dimension is embodied in the vampire in the form of an androgynous man extremely experienced in the matters of the heart, sexually adroit, and with a deep knowledge of human economic motivations; a man that embodies combined 'alternative' masculine practices (Carabí and Armengol 2015).

\section{CONCLUSIONS ON DESIRABLE MASCULINITIES}

Thanks to a great effort on the part of feminist thinkers, Women's and Men's Studies have revealed the social and cultural dimensions that shape our notions of what it means to be a woman and a man, what are considered to be typically feminine and typically masculine characteristics, and what types of gender performance guarantee social acceptance and recognition. These forms are constructed in dialectical opposition and vary from one social context to another. Different ideals/practices of being a man come into tension with one another and in opposition to the modes in which a desirable form of femininity emerges.

In relation to types of masculinity, hegemonic masculinity is the idealized form, the most desirable among many, at a given place and time. It represents the socially dominant gender construction that subordinates femininities as well as other forms of masculinity, and shapes men's social relationships with women as well as relations between men. Furthermore, hegemonic masculinity represents a particular culturally coded form of exercising power and authority on a micro/macro level. 
According to some critics (Kimmel 2013; Connell 1995; Connell and Wood 2005) today in the United States, hegemonic masculinity is embodied in heterosexual, European American men that tend to feel displaced and threatened by economic, social, and political changes that have reshaped their lives. In some cases, this feeling of 'crisis' can lead to the use of violence, perceived as a legitimate reaction to reassert their power over women and other men (Thiebaut 2010). Hamilton narratives offer a fictional alternative of how the figure of androgyny in a text symbolically serves as a valid counterpart. If the Hard and the Soft alternatives, as two extremes of a spectrum of manliness, leave men mutilated (either sociopathic with a propensity to exercise violence against women or unable to maintain sexual tension in their relationships with women, and incapable of dealing with working environments), the androgynous represents a form of being in the world that allows people to strategically embrace femininity and masculinity instead of performing a set of limited gendered roles and behaviours. In the reading I have provided, the androgynous vampire represents a form of resistance to hegemonic white American masculinity and its historical debt to violence and phobia against otherness. In other terms, being a liminal figure that moves beyond Hard masculinity and the Soft ideal, the vampire allows forms of resistance to gender discursive practices to emerge. Indeed, Hamilton contributes significantly to the re-inscription of the vampire canon. Her writing can be inscribed in the game of reversing traditional notions of what vampirism represents for women: instead of being a source of death and the final renunciation of autonomy, Anita's relationship with the vampire is a preferential path to gain emotional security and power and to become an equal partner in a wealthy empire.

In conclusion, I would like to stress once more that symbolically the androgynous provides a model for a fluid notion of personal identity not so inherently controlled by gender. Considering that most of Hamilton's characters are androgynous beings, the author seems to find traditional restrictive notions of femininity and masculinity undesirable for women, and her success as a writer makes me wonder whether the appeal that this popular vampire fiction exercises on female readers resides indeed on its ability to provide an alternative model companion for a heroine that navigates the ever-changing tides of our gendered world.

\section{REFERENCES}

Adams, R. and D. Savran. 2002. The Masculinity Studies Reader. Oxford: Blackwell. Auerbach, N. 1995. Our Vampires, Ourselves. Chicago: The University of Chicago Press. 
Badinter, E. 1992. XY de L'identité masculine. Paris: Odile Jacob. [(1993) XY: La Identidad Maculina. Madrid: Alianza Editorial].

Butler, J. 1990. Gender Trouble. Feminism and the Subversion of Identity. New York: Routledge.

Carabí, A. and J. M. Armengol, eds. 2015. Masculinidades alternativas en el mundo de boy. Barcelona: Icaria.

Connell, R. W. 1995. Masculinities. Los Angeles: University of California Press.

Connell, R. W. and J. W. Messerschmidt. 2005. "Hegemonic Masculinity: Rethinking the Concept". Gender Society 19: 829-859.

Connell, R. W. and J. Wood. 2005. "Globalization and Business Masculinities". Men and Masculinities 7 (4): 347-364.

Courtenay, W. 2000. "Constructions of masculinity and their influence on men's well-being: a theory of gender and health". Social Science \& Medicine 50 (10): 1385-1401.

Crawford, J. 2014. The Twilight of the Gothic? Vampire Function and the Rise of the Paranormal Romance 1991-2012. Cardiff: University of Wales Press.

Duclos, D. 1998. The Werewolf Complex: America's fascination with violence. Oxford: Berg.

Faludi, S. 1999. Stiffed. The Betrayal of the American Man. New York: Arper Collins.

Garber, M. 1992. Vested Interests: Cross Dressing and Cultural Identity. New York: Routledge.

Gibbons, A. 1992. The Transformation of Intimacy. Sexuality, Love and Eroticism in Modern Societies. Stanford: Stanford University Press.

Goodlad, L. 2007. "Looking for Something Forever Gone: Gothic Masculinity, Androgyny, and Ethics at the Turn of the Millennium". Cultural Critique 66 (Spring): 104-126.

Halberstam, J. 1993. "Technologies of Monstrosity: Bram Stoker's 'Dracula'". Victorian Studies 36 (3), Victorian Sexualities (Spring): 333-352.

Halberstam, J. 1998. Female Masculinity. Duhram: Duke University Press.

Hamilton, L. 1993. Guilty Pleasures. New York: Orbit.

Hamilton, L. 1994. The Laughing Corpse. New York: Orbit.

Hamilton, L. 1995. The Circle of the Damned. New York: Orbit.

Hamilton, L. 1996. The Lunatic Cafe. London: Hachette.

Hamilton, L. 1997. The Killing Dance. New York: Orbit.

Hamilton, L. 2001. Narcissus in Chains. New York: Orbit. 
NARRATIVE REPRESENTATIONS OF MASCULINITY. THE HARD WEREWOLF AND THE ANDROGYNOUS ...

Heilbrun, C. 1964. Toward a Recognition of Androgyny. New York: Northon and Company.

Holland-Toll, L. 2004. "Harder than Nails, Harder than Spade: Anita Blake as 'The Tough Guy' Detective”. The Journal of American Culture 27 (June): 175-189.

Horlacher, S., ed. 2011. Constructions of Masculinity in British Literature from the Middle Ages to the Present. New York: Palgrave Macmillan.

Kimmel, M. 2013. Angry White Men: American Masculinity at the End of an Era. New York: Nation Books.

Mamatas, N. 2010. "Giving the Devil Her Due". Ardeur. 14 Writers on the Anita Blake: Vampire Hunter Series. Ed. L. K. Hamilton. Dallas: BenBella. 3-10.

Mirizio, A. 2000. "Del Carneval al Drag: La extraña relación entre masculinidad y trasvestismo". Nuevas Masculinidades. Eds. M. Segarra and A. Carabí. Barcelona: Icaria. 133-150.

Moretti, F. 1982. "The Dialectic of Fear". New Left Review 136 (Nov.-Dec): 67-85.

Morgan, E. 1987. "The Feminist Novel of Androgynous Fantasy". Frontiers: A Journal of Women Studies 2 (3): 40-49.

Mukherjea, A. 2011. "My Vampire Boyfriend: Postfeminism, 'Perfect' Masculinity, and the Contemporary Appeal of Paranormal Romance". Studies in Popular Culture 33 (2, Spring): 1-20.

Norwood, R. 1985. Women that love too much. New York: Pocket Books.

Radway, J. 1991. Reading the Romance. Women, Patriarchy and Popular Literature. Chapel Hill: The University of North Carolina.

Rodgers C. 1995. "Elisabeth Badinter and 'The Second Sex': An Interview". Signs 21, 1 (Autumn): 147-162.

Rubin, G. 1975. "The Traffic of Women: Notes on the Political Economy of Sex". Toward an Anthropology of Women. Ed. R. R. Reiter. New York: Monthly Review Press. 157-211.

Saukko, P. 2003. Doing Research in Cultural Studies. An Introduction to Classical and New Methodological Approaches. London: Sage.

Siegel, C. 2007. "Female Heterosexual Sadism: The Final Feminist Taboo in Buffy the Vampire Slayer and the Anita Blake Vampire Hunter Series". Third Wave Feminism and Television: Jane Puts it in a Box. Ed. M. L. Johnson. London/ New York: Tauris. 56-90.

Thibaut, C. 2010. "Violencia de género y la hipótesis de la violencia anómica". Historia y Pensamiento en torno al género. Eds. M. Huguet and C. González Marín. Madrid: Dykinson. 135-158. 
Veldman-Genz, C. 2011. "Serial Experiments in Popular Culture: The Resignification of Gothic Symbology in Anita Blake Vampire Hunter and the Twilight Series". Bringing Light to Twilight, Perspectives on a Pop Culture Phenomenon. Ed. G. L. New York: Palgrave. 43-59.

Whitehead, S. 2002. "Masculinity-Illusion or Reality". Men and Masculinities. Key Themes and New Directions. Ed. S. Whitehead. Malden: Polity Press. 8-44.

Wicke, J. 1992. "Vampiric Typewriting: Dracula and Its Media". ELH 59 (2, Summer): 467-493.

Woodhill, B. M. and Samuels C. A. 2004. "Desirable and Undesirable Androgyny: a Prescription for the Twenty-First Century". Journal of Gender Studies 13 (1, March): 15-28. 